\title{
MONETARY POLICY TRANSMISSION MECHANISMS IN THE CENTRAL AND EASTERN EUROPEAN COUNTRIES
}

\section{Abstract}

Objective: The aim of this study is to examine monetary policy transmission mechanisms in four Central and Eastern European countries (the Czech Republic, Hungary, Poland and Romania), in the presence of fiscal and exchange rate effects.

Research Design \& Methods: We implement a structural vector autoregression (SVAR) approach for modelling the interdependencies between monetary and fiscal policies, output gap and consumer price inflation (CPI). In our six-variable model, which includes the budget balance, the output gap, CPI, the central bank reference rate, the lending rate and the real exchange rate (RER), short-run restrictions on the contemporaneous structural parameters imply that the budget balance responds to changes in the output gap and lending rate, while the central bank reference rate is a function of output and inflationary shocks.

Findings: The results of our research show that the effects of an increase in the central bank's short-run interest rate on inflation, output gap and the RER are quite heterogeneous across the CEE countries. As the monetary policy response to inflation seems to be significant and rather uniform across countries, though with a different time pattern, there is no evidence of its reaction to the output gap (except for Romania in the long run). Among other results, budget surplus has a strong anti-inflationary impact in all countries but at the expense of a short-lived output slowdown (except for Hungary). The RER undervaluation is likely to stimulate output (Romania) or depress it (Poland), with a neutral stance in the two other countries. As expected, an increase in the lending rate is followed by a fall in output on impact, while there is no significant effect on inflation.

Viktor Shevchuk, Cracow University of Technology, Institute of Economy, Sociology and Philosophy, Warszawska 24, 31-155 Kraków, Poland, e-mail: vshevchuk@pk.edu.pl, ORCID: https://orcid. org/0000-0002-7125-1267.

This is an open access article distributed under the terms of the Creative Commons Attribution-NonCommercial-NoDerivatives 4.0 License (CC BY-NC-ND 4.0); https://creativecommons.org/ licenses/by-nc-nd/4.0\%. 
Implications/Recommendations: Our study argues in favour of a much stronger response of the central bank reference rate to the output gap in the CEE countries. As suggested by the experience of Poland, an immediate response of the central bank to inflation could explain the lack of the price puzzle when an increase in the reference rate is associated with a sustained increase in consumer prices. An anti-inflationary monetary policy stance should be strengthened by fiscal tightening, while in a recession a higher budget deficit is likely to boost output and prevent a deflationary spiral.

Contribution: The article presents the application of the extended IS-MP-IA model to the modelling of monetary policies by the central banks of the CEE countries that practice a floating exchange rate regime.

Keywords: inflation, output gap, budget balance, central bank reference rate, Central and Eastern European countries.

JEL Classification: C5, E5, H6.

\section{Introduction}

Since the beginning of the 2000s, exchange rate flexibility has become a distinct feature of the monetary policy framework in the Central and East European (CEE) countries (the Czech Republic, Hungary, Poland and Romania). However, the free floating regime does not guarantee that an efficient interest rate policy will attain the inflationary target at the natural level of output. Running counter to the earlier perception of free floating as a precondition for independent monetary policy, monetary policy transmission mechanisms become more complicated in the presence of exchange rate effects on price and output dynamics. In a recent study of 19 inflation-targeting emerging economies, Pourroy (2013) finds that the probability of those countries having a perfectly flexible arrangement as developed economies do is $52 \%$, while the probability of having a managed float system with foreign exchange market intervention is $28 \%$, and that of having a rigid exchange-rate system (similar to those of pegged currencies) is $20 \%$. In this context, it is reasonable to consider monetary policy outcomes in connection with exchange rate effects. On the other hand, monetary policy transmission mechanisms can be modified in the presence of fiscal policy constraints, which is a quite realistic assumption for the CEE countries. For example, Crespo-Cuaresma, Eller and Mehrotra (2011) state that monetary policy in the CEE countries usually offsets domestic fiscal expansion, while fiscal policy can be used to accommodate interest rate shocks. The importance of combining monetary and fiscal policy mechanisms in empirical studies has been recently highlighted in a study on Poland's economy (Haug, Jędrzejowicz \& Sznajderska 2019, pp. 15-27). 
As interest rate decisions made by the central bank are universally discussed in terms of Taylor rules, which describe policy rates as responding to inflation and some measure of the output gap (Cúrdia et al. 2015, pp. 72-83), attention is drawn to the macroeconomic effects of the central bank (CB) reference rate. As implied by the IS-MP-IA (or Taylor-Romer) model, the inflation target can be achieved by setting the $\mathrm{CB}$ policy rate at the level of the natural rate of interest, with both output gap and expected inflation accounted for. However, there are findings of a positive correlation between the $\mathrm{CB}$ reference rate and inflation known as a "price puzzle" (Hanson 2004, pp. 1385-413; Cochrane 2016), which cannot but complicate monetary policy. In a similar fashion, evidence is not lacking that it is an increase in the interest rate that leads to output growth (see, for example, Lee \& Werner 2018, pp. 26-34). Also, monetary transmission mechanisms used to be dependent upon exchange rate effects, with fiscal policy also playing its part.

The aim of this study is to examine monetary policy transmission mechanisms in four CEE countries in the presence of fiscal and exchange rate effects. We implement a structural vector autoregression (SVAR) approach for modelling the interdependencies between monetary and fiscal policies, output gap and CPI.

The rest of the paper is organized as follows: Section 2 provides a brief outline of analytical issues. Section 3 reviews relevant empirical studies. Section 4 describes the data and outlines the structure of the SVAR model. Section 5 discusses empirical results and Section 6 offers some concluding remarks.

\section{Analytical Framework}

As proposed by Romer (2000, pp. 149-69), the IS-MP-IA model is considered a simple but informative tool applied in the analysis of the inflation-output relationship and monetary policy effects by focusing on the interest rate rather than on money supply. While traditional IS and Phillips curves are retained, the LM curve is replaced with a Taylor-type interest rate (Taylor 2000). When extended by fiscal variables (Bofinger, Mayer \& Wollmershauser 2006, pp. 98-117), the modelling framework enables analysis of the fiscal policy effects as well. In the case of open economies, it is suggested that the real exchange rate (RER) be included in the reaction function (Ball 1999, pp. 127-56; Caporale et al. 2018, pp. 306-19; Heipertz, Mihov \& Santacreu 2017, Nojković \& Petrović 2015, pp. 577-95), but such an approach is also 
criticised (Leitemo \& Söderström 2005). As the RER affects both aggregate demand and inflation, it further complicates the monetary policy.

The extended IS-MP-IA model is presented below:

$$
\begin{gathered}
y=\alpha_{0}-\alpha_{1}\left(1-p^{e}\right)-\alpha_{2} b+\alpha_{3} q, \\
i=\bar{r}+p^{e}+\gamma_{1}(p-\bar{p})+\gamma_{2} y+\gamma_{3} q, \\
p=p^{e}+\beta_{1} y+\beta_{2} q,
\end{gathered}
$$

where $y$ is the real output gap, $q$ is the RER gap (an increase in the value of $q$ means undervaluation of the real exchange rate), $b$ is the budget surplus, $i$ is the CB reference rate, $\bar{r}$ is the "natural" rate of interest, $p$ and $p^{e}$ are actual and expected inflation rates, respectively, and $\bar{p}$ is the inflationary target.

The first equation is the IS curve, characterizing the inverse relationship between the $\mathrm{CB}$ reference rate (in real terms) and output. The budget surplus and the RER overvaluation are expected to be contractionary. Equation (2) presents a Taylor-type monetary policy rule that implies the response of the CB reference rate to the inflation, output and RER gaps. Although accounting for the exchange rate is not required in the case of developed economies, it might be of importance in emerging economies (Caporale et al. 2018, pp. 306-19). In equation (3), the aggregate supply is given by the positive short-run open economy Phillips curve. Lags of the variables entering the model could be added.

The monetary policy reaction to an expansionary demand shock and further developments are explained in Figure 1. Initially, higher government deficit or exchange rate depreciation lead to an increase in output above its equilibrium level, with a rightward shift of both IS and AD schedulers. In response to a positive output gap, there is a gradual increase in the inflation rate, especially if the demand shock is caused by the RER undervaluation. As implied by the Taylor-type monetary policy response, both the output gap and acceleration of inflation are followed by an increase in the $\mathrm{CB}$ reference rate. The higher interest rate plays an instrumental role in closing the output gap. If the demand shock is not reversed, the economy shifts to a new equilibrium with higher levels of both inflation and interest rate. In order to return to the initial equilibrium at $p_{0}$ and $i_{0}$, fiscal austerity or exchange rate appreciation are necessary.

As the fiscal deficit is expansionary in the IS-MP-IA model, there is an ambiguity with respect to the exchange rate effects. On the surface, nominal (real) exchange rate depreciation is expansionary when it is neutral with respect to the interest rate. However, exchange rate depreciation 
can be contractionary even if there is no increase in the interest rate. By incorporating the Marshall-Lerner condition and disposable income into the net export function, Shieh (2006, pp. 65-70) demonstrates that currency devaluation may improve the trade balance and depress domestic economic activity without the assumption that the sum of export and import price elasticities should exceed unity. It is argued that the modified model can be viewed as an important alternative to the short-run international macroeconomic model.
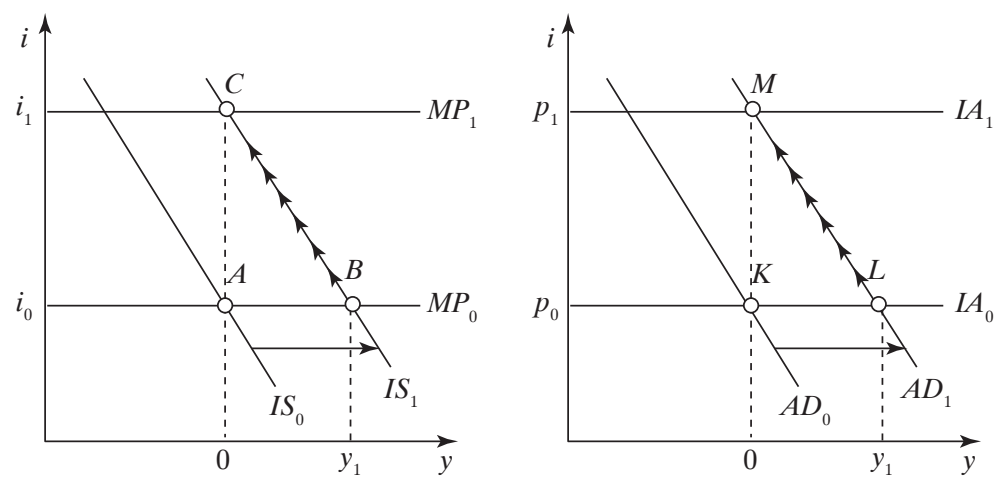

Fig. 1. Macroeconomic Adjustment for an Expansionary Demand Shock Source: elaborated by the author.

As demonstrated by an open-economy model with external habits, pre-announcement of the rate of expected currency appreciation by taking into account inflation and output fluctuations can outperform the standard Taylor rule in terms of welfare, regardless of the policy parameter values (Heipertz, Mihov \& Santacreu 2017). Exchange rate instability can help reduce price volatility (Ball 1999, pp. 127-56) or lead to welfare gains (Heipertz, Mihov \& Santacreu 2017). However, this approach is also criticised. For example, it is argued that the Taylor rule without exchange rates seems to be more robust in modelling uncertainty in the open economy (Leitemo \& Söderström 2005, pp. 481-507).

\section{Survey of Relevant Empirical Studies}

The policy implications of the IS-MP-IA model in general and the Taylor rule in particular are extensively empirically tested. For the CEE countries, a clear shift in interest rate setting towards targeting inflation is found in the Czech 
Republic, Hungary and Poland, with somewhat weaker results for Slovenia and Romania (Frömmel, Garabedian \& Schobert 2011, pp. 807-18). Similar results have been obtained more recently in several other studies (Arlt \& Mandel 2014, pp. 269-89; Căpraru, Moise \& Rădulescu 2015, pp. 91-102; Feldkircher, Huber \& Moder 2016, pp. 8-27; Ryczkowski 2016, pp. 363-392; Wang et al. 2015, pp. 665-85). Recently, no "price puzzle" has been found for monetary policy in Poland (Haug, Jędrzejowicz \& Sznajderska 2019, pp. 15-27). Some studies suggest that the central banks in the CEE countries react more strongly to upward deviations from the inflation and output thresholds (Klose 2019, pp. 31-49; Paez-Farrell 2007, pp. 1-11), but such an outcome can be country-specific (Vašiček 2012, pp. 235-63). However, there are empirical results which show that the dominant monetary policy regimes in the Czech Republic, Hungary and Poland are characterized by little response to inflation and output gap developments (Mackiewicz-Łyziak 2016, pp. 133-52).

There is empirical evidence that central banks in the Czech Republic, Poland, Hungary and Serbia react to the RER gap, while in Romania and Albania there is a response to the changing rate of RER (this implies that only accelerated RER developments affect policy decisions concerning the interest rate, while the constant rate of change does not trigger any policy shifts) (Nojković \& Petrović 2015, pp. 577-95). The orientation of central banks in the CEE countries towards stabilization of the exchange rate and real economic activity is supported by other studies (Popescu 2014, pp. 1113-1121). While a dominant monetary reaction to inflation is found for the Czech Republic and Poland, Hungary seems to be more exchange ratefocused (Orlowski 2010, pp. 148-59). A recent study has shown that nominal exchange rates in the CEE countries are not disconnected from the macro-fundamentals implied by the Taylor rule-based model (Dąbrowski, Papież \& Śmiech 2018, pp. 2273-96). In several emerging countries (Indonesia, Israel, South Korea, Thailand, Turkey) the exchange rate has an impact on the reaction function of monetary authorities under a high inflation regime but not under a low inflation regime (Caporale et al. 2018, pp. 306-19). However, the majority of empirical studies for the CEE countries do not reveal monetary policy reactions to exchange rate developments (Frömmel, Garabedian \& Schobert 2011, pp. 807-18).

In a wider context, exchange rate pass-through and commodity price effects are used to explain a "price puzzle", when a positive interest rate shock brings about an immediate increase in the inflation rate (Hanson 2004, pp. 1385-413). In general, empirical evidence suggesting that raising 
interest rates lowers inflation is weak, with the more plausible result that monetary tightening is associated with lower output (Cochrane 2016). It is argued that anti-inflationary actions must combine fiscal and monetary policies. Within the IS-MP-IA modelling framework, results in favour of exchange rate depreciation as a pro-growth factor are found for South Korea (Clark \& Hsing 2005, pp. 297-11), with the opposite outcome for the Czech Republic (Hsing 2004, pp. 339-45), Poland (Hsing 2005, pp. 44-50) and Serbia (Hsing \& Morgan 2017, pp. 24-30). As obtained in the process of testing the theoretical predictions of the IS-MP-IA model, deficit spending is expansionary in the Czech Republic (Hsing 2004, pp. 339-45), Serbia (Hsing \& Morgan 2017, pp. 24-30) and South Korea (Clark \& Hsing 2005, pp. 297-311). For the Southeastern European economies (Albania, Bosnia and Herzegovina, Macedonia and Serbia), it is exchange rate appreciation and fiscal prudence that stimulate output (Apostolov \& Josevski 2015, pp. 131-57). Similar conclusions are drawn in a wider study of $13 \mathrm{CEE}$ and former Soviet countries (Josheski \& Eftimoski 2016, pp. 5-13).

\section{Data and Statistical Model}

All the data samples for the Czech Republic (2001Q1:2017Q3), Hungary (2001Q1:2017Q3), Poland (2001Q1:2017Q3) and Romania (2004Q1:2017Q3) were obtained from the IMF International Financial Statistics (IFS) online database. The quarterly series used in the SVAR are the CB reference rate $(\%), i_{t}$, lending rate $(\%), r l_{t}$, CPI (\%), $p_{t}$, the budget balance (\% of GDP), $b_{t}$, the cyclical components of real output (index, $\left.2010=100\right), y_{t}$, and RER (index, $2010=100$ ), $q_{t}$. Both $y_{t}$, and $q_{t}$ are calculated as the difference between the current and trend values given by the Hodrick-Prescott filter. All output series were seasonally adjusted using the Census X12 procedure. Both the Augmented Dickey-Fuller (ADF) and Phillips-Perron (PP) stationarity tests indicate that most of the macroeconomic variables are stationary at the 5\% significance level (not reported).

Structural VARs enable us to separate out systematic responses to changes in interest rates from exogenous monetary policy shocks. Omitting the details of a general specification for the economy described by a structural form equation of a linear, stochastic dynamic form, our SVAR presents as follows (in terms of the contemporaneous innovations):

$$
\begin{aligned}
& b=u_{1}+a_{12} y+a_{15} r l, \\
& y=u_{2}+a_{24} i+a_{26} q,
\end{aligned}
$$




$$
\begin{gathered}
p=a_{31} b+a_{32} y+u_{3}, \\
i=a_{42} y+a_{43} p+u_{4}, \\
r l=a_{53} p+a_{54} i+u_{5}, \\
q=a_{61} b+a_{62} y+a_{63} p+a_{64} i+a_{65} r l+u_{6} .
\end{gathered}
$$

All variables in equations (4)-(9) represent the first stage VAR residuals. It is assumed that the budget balance responds to changes in the output gap and lending rate (equation (4)). As implied by the IS curve, the output gap is influenced by the CB reference rate and the RER gap (equation (5)). Inflation in the current period is affected by fiscal policy and the output gap (equation (6)). Thus, it is assumed that monetary policy exerts its inflationary effects through its impact on the output gap. As argued by Giordani (2004, pp. 1271-96), using the output gap instead of the level of real output helps to avoid the price puzzle when monetary tightening does not bring about a deceleration of inflationary dynamics.

The CB reference rate is a function of output and CPI shocks (equation (7)). The lending rate reacts to changes in inflation and the $\mathrm{CB}$ reference rate (equation (8)). It is presumed that the correction of RER misalignment is not among central bank priorities in the short run. Finally, the RER gap is influenced by all other endogenous variables in the current period (equation (9)).

Among exogenous variables, our SVAR includes a dummy variable to control for the financial turmoil of 2008-2009. In the estimation, we use five to six lags of each endogenous variable, as implied by most of the lag length criteria. It is worth mentioning that using the London Interbank Offer Rate (LIBOR) as an exogenous variable does not significantly change the results.

\section{Estimation Results}

The impulse response functions to an unexpected increase in the $\mathrm{CB}$ reference rate are presented in Figure 2. The confidence bands are generally large enough, but it is possible to draw several conclusions. Poland is the only country with a statistically significant, albeit short-lived anti-inflationary effect of a higher $\mathrm{CB}$ reference rate. In the Czech Republic inflation declines on impact, but there is a significant rebound of consumer prices with a 5-quarter lag. Hungary and Romania do illustrate the "price puzzle", as central bank rate hikes lead to a higher inflation rate in a year, with no price decreases in the short run. Obviously, our results do not reject the incidence of the "price puzzle" on a country-specific basis, even if one 
controls for exchange rate and fiscal policy effects. Among other factors that used to be considered in the context of the "price puzzle", commodity prices are left to future research.
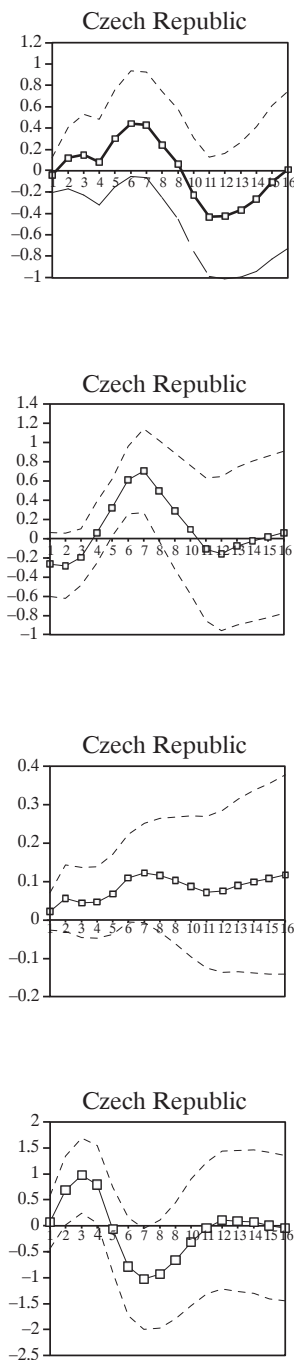
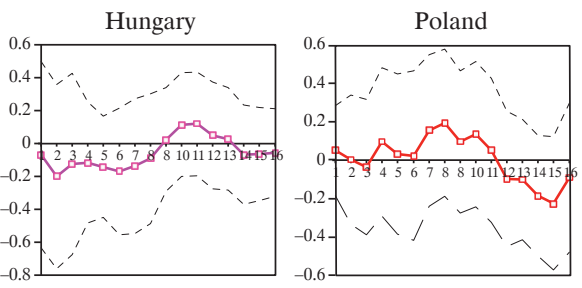

a) on the output gap
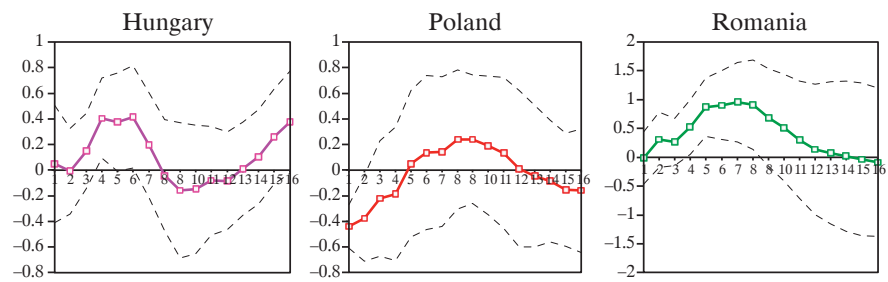

b) on consumer price inflation
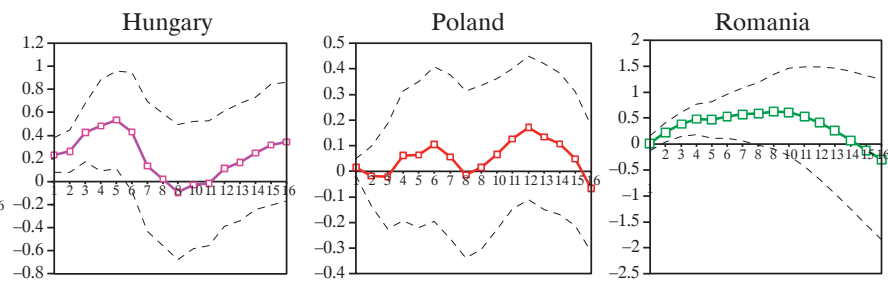

c) on the lending rate
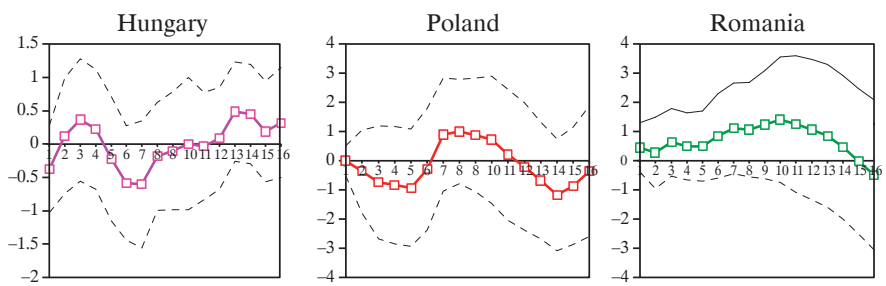

d) on the RER

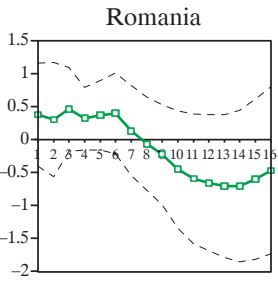


The output gap does not react to a tightening of monetary policy in Hungary and Poland, with a counter-intuitive expansionary effect observed in the Czech Republic and Romania. As expected, an increase in the central bank reference rate is followed by a strong response of the lending rate in Hungary and Romania, while similar developments in the Czech Republic are much weaker. For Poland, the money market rate seems to be neutral with respect to central bank interest rate policy.

Monetary tightening is likely to bring about RER appreciation in the Czech Republic only, following a short-lived depreciation of the RER on impact. Romania is an example of a lasting depreciation effect. Developments in the RER in Hungary and Poland seem to be neutral with respect to the central bank interest rate policy.

The forecast error variance decomposition (FEVD) indicates that monetary shock is responsible for up to $50 \%$ of inflation volatility on impact in Poland, but in a year the fraction of $i_{t}$ declines to $20 \%$. In Romania it is just the opposite, with the initial share at $6 \%$, gradually increasing to $46 \%$ in two years. A similar pattern is observed in the Czech Republic. In Hungary the share of $i_{t}$ in changes of $p_{t}$ does not exceed $18 \%$ at any horizon. The share of $i_{t}$ in changes in the output gap is much smaller, ranging from $8 \%$ in Hungary to $25 \%$ in Romania. As expected, the interest rate is most affected by the CB reference rate in Hungary (40\%) and Romania (34\%). The contribution of $i_{t}$ to the RER gap is at the lowest level in Hungary (8\%) and Poland (17\%) and at the highest in the Czech Republic (35\%).

The monetary policy reaction to endogenous shocks is presented in Figure 3. The response to the output gap is rather weak, especially in the short run. For Poland, Romania and the Czech Republic (to a lesser extent), there is weak evidence of a pro-cyclical decline in the central bank reference rate on impact, running counter to the standard Taylor rule. However, this policy is reversed in the long run in Romania. No reaction to the output gap at all is found for Hungary. Based on our estimates, it is possible to agree with Darvas (2006, pp. 140-55) that monetary policy is most powerful in Poland and is least powerful in Hungary, while the strength of monetary policy in the Czech Republic lies in between.

Monetary response to inflation is immediate and significant in Poland. A similar pattern of the response function is observed in Hungary, though with a somewhat slower but stronger reaction to the price shock. For the Czech Republic and Romania, an increase in the CB reference rate is persistent but rather weak. While it is possible to confirm the findings of Mackiewicz-Łyziak (2016, pp. 133-52) that there is a rather weak monetary 
policy response to the output gap in the CEE countries, this is not the case with the response to inflation. Our results are in line with the majority of previous studies that report high preferences for targeting inflation in interest rate setting, for example Frömmel, Garabedian and Schobert (2011, pp. 807-18), Arlt and Mandel (2014, pp. 269-89), and Wang et al. (2015, pp. 665-85).
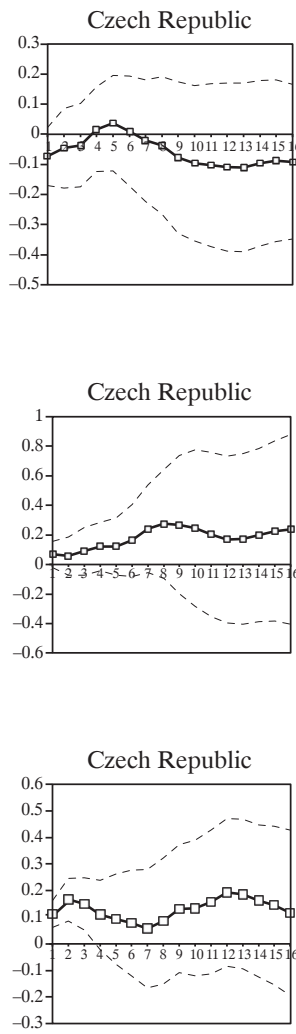
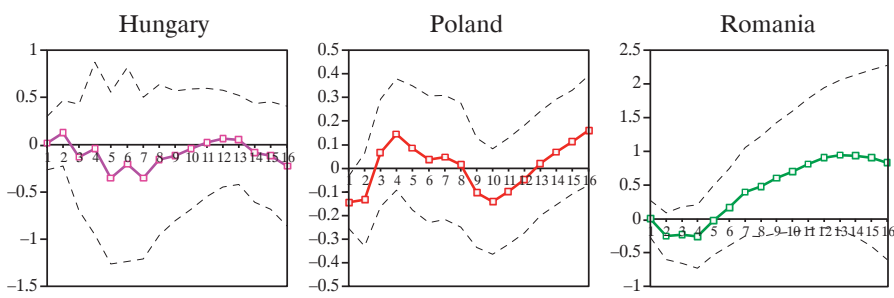

a) to the output gap
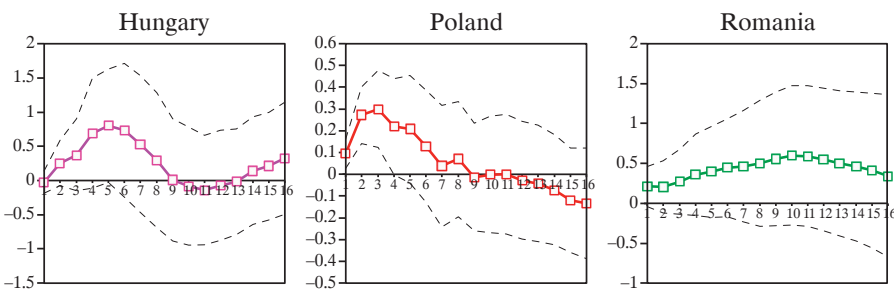

b) to consumer price inflation
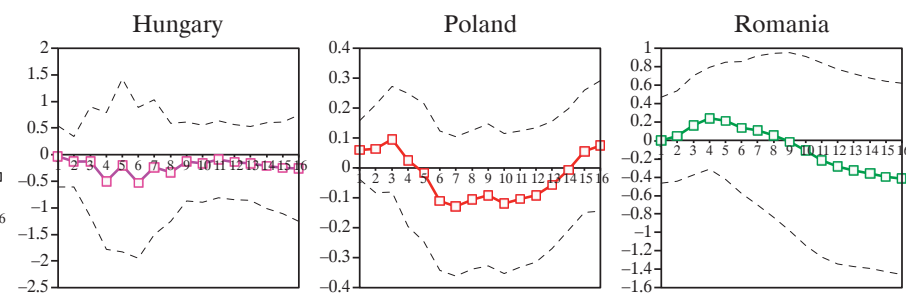

c) to RER undervaluation

Fig. 3. Monetary Policy Reaction to Macroeconomic Shocks Source: author's own calculations.

Monetary policy reaction to RER undervaluation is found for the Czech Republic only. It runs counter to the results of several studies that imply a central bank response to exchange rate fluctuations, for example Nojković \& Petrović (2015, pp. 577-95), Popescu (2014, pp. 1113-21) and Orlowski (2010, pp. 148-59). In the spirit of the findings by Caporale et al. 
(2018, pp. 306-19) for several emerging economies, it is possible to argue that a weak reaction of monetary policy to exchange rate fluctuations results from success in attaining a low inflation.

The FEVD confirms that the contribution of both inflation and output gap shocks to the CB reference rate is very strong in Poland $-50 \%$ and $32 \%$, respectively. In the Czech Republic and Hungary price shock determines $26 \%$ and $35 \%$ of changes in $i_{t}$, while the share of the output gap is much smaller at $14 \%$ and $5 \%$, respectively. Romania is the only country where the output gap shock is more important than the price shock, with the share in the FEVD of $i_{t}$ at $35 \%$ and $20 \%$, respectively. The Czech Republic is the only country with a significant share of the RER in the FEVD of $i_{t}$ at $46 \%$. For all other countries, the RER gap determines no more than $11 \%$ of changes in the $\mathrm{CB}$ reference rate at any horizon.

The output gap is associated with inflation in Poland, with the share of $y_{t}$ in the FEVD of $p_{t}$ at $18 \%$ (Figure 4). Undervaluation of the RER contributes to inflation in the Czech Republic and Romania (to lesser extent), with the share of $q_{t}$ in the FEVD of $p_{t}$ at $45 \%$ and $18 \%$, respectively. No effects are noticed in Hungary and Poland. There is no difference between CEE countries in that budget surplus brings about a decrease in inflation, though at different time horizons. The fiscal variable determines up to $48 \%$ of inflation in the Czech Republic and 43\% in Hungary, in both countries with a significant lag of 7 to 8 quarters. For Poland and Romania the fraction of changes in inflation explained by the budget balance is at a maximum of $24 \%$ and $17 \%$, respectively. Among other results, an increase in the lending rate is anti-inflationary only in Poland and neutral with respect to price dynamics for other countries. Inflation is inertial in the short run for all CEE countries, except for the Czech Republic.

As seen in Figure 5, the budget surplus is contractionary on impact in all countries, except Hungary. In the case of expenditure cuts or tax increases, this can be a problem for the Czech Republic, where the share of $b d_{t}$ in the FEVD of $y_{t}$ is as high as $70 \%$ on impact, then declining to $49 \%$ at longer horizons. An expansionary effect of fiscal prudence is likely to materialize in the long run for Romania. It is worth noting that empirical testing of the IS-MP-IA model for the CEE and former Soviet countries is rather inconclusive, as deficit spending can be either expansionary (Hsing 2004, pp. 339-45; Hsing \& Morgan 2017, pp. 24-30) or contractionary (Apostolov \& Josevski 2015, pp. 131-57; Josheski \& Eftimoski 2016, pp. 5-13).

Inflation seems to be expansionary in the short run in Hungary and Poland, with a contractionary effect in Romania (a neutral stance is 

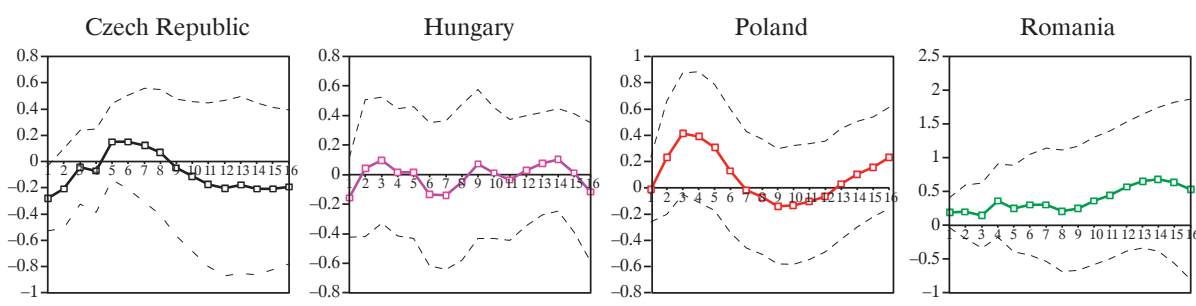

a) the output gap
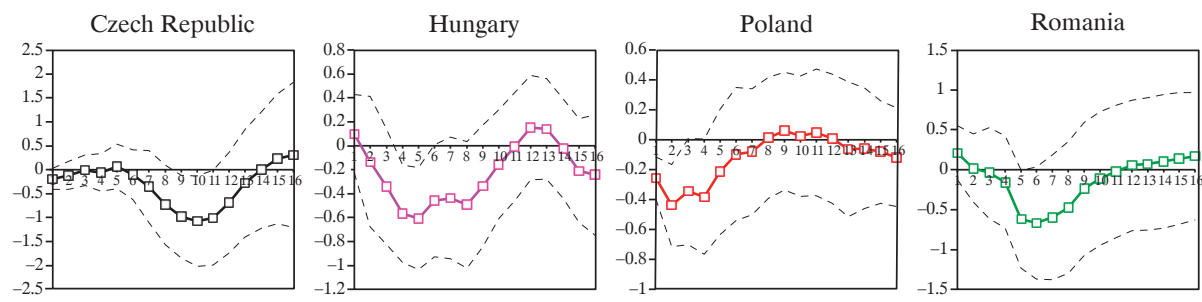

b) the budget balance
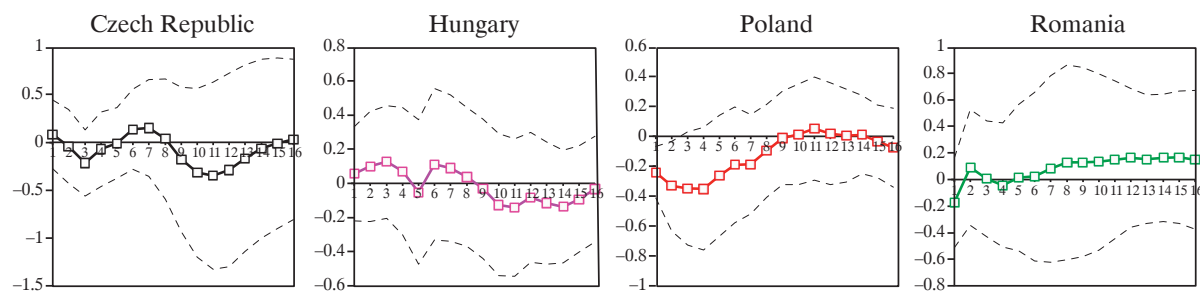

c) lending rate
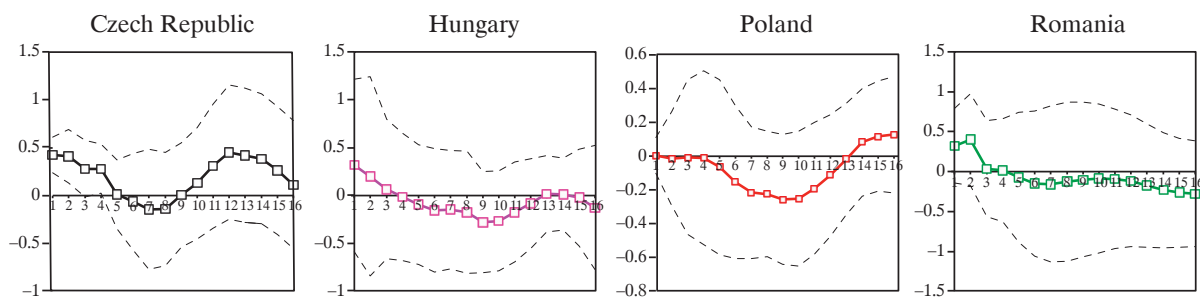

d) the RER gap

Fig. 4. Selected Non-monetary Determinants of Inflation

Source: author's own calculations.

observed in the Czech Republic). Assuming that price dynamics explains about $45-64 \%$ of changes in the output gap in Hungary and 50\% in Poland, price incentives are very important for the business cycle in both countries. 

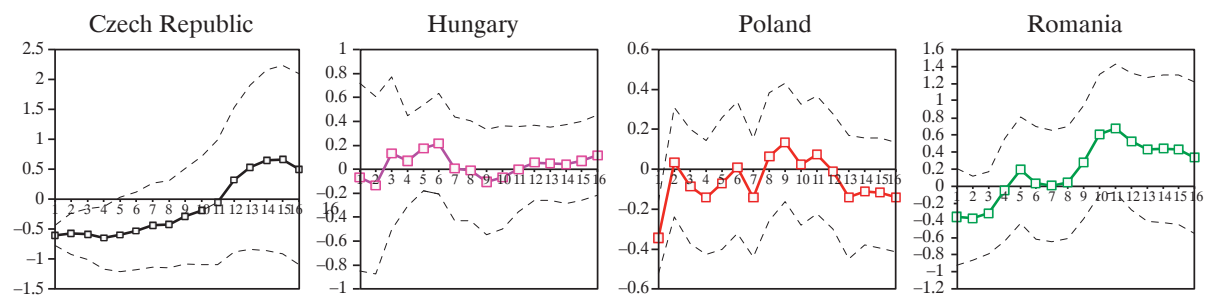

a) the budget balance
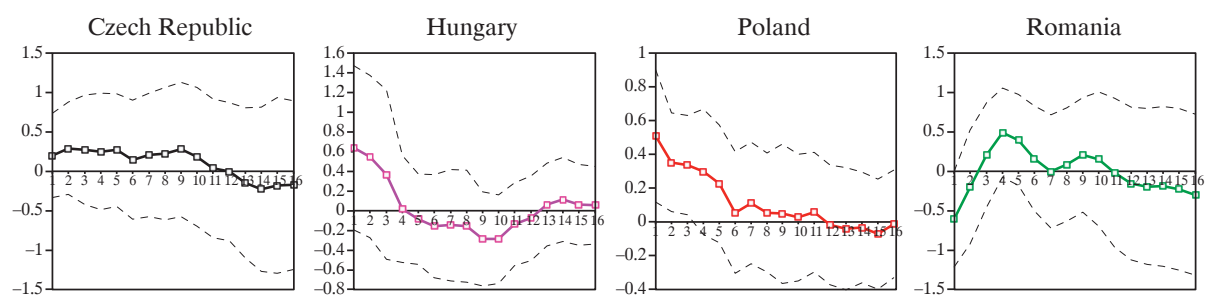

b) inflation
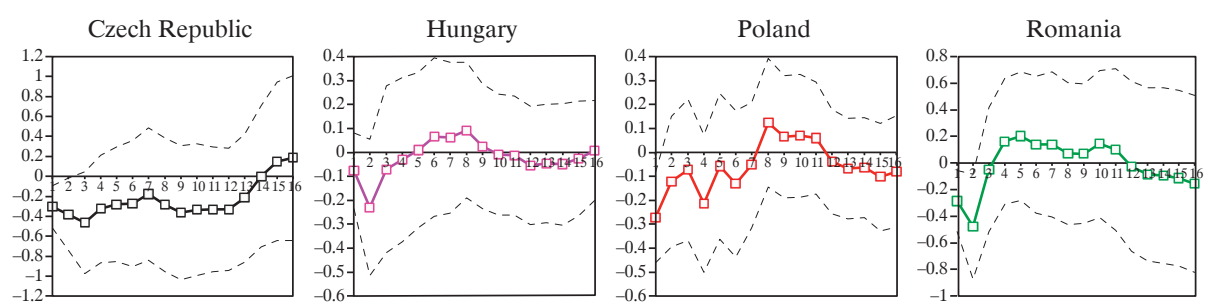

c) lending rate
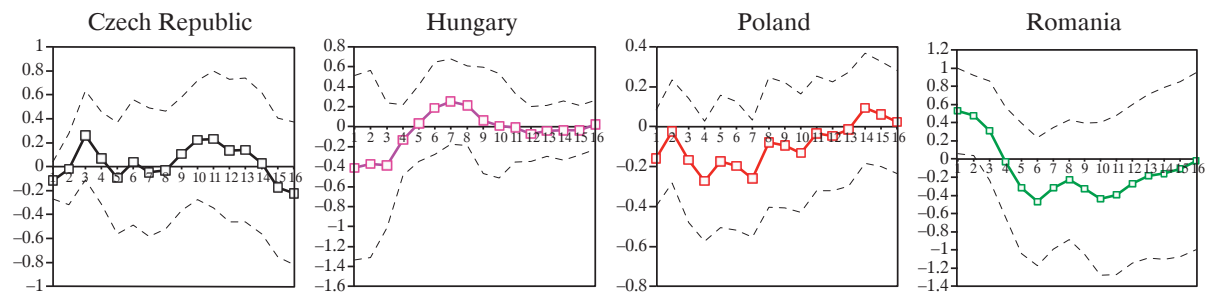

d) the RER gap

Fig. 5. Selected Determinants of the Output Gap Source: author's own calculations.

An increase in the lending rate is expected to produce a contractionary effect, with the share in the FEVD of $y_{t}$ ranging from as low as $4 \%$ in Hungary to $25 \%$ in Romania. 
Undervaluation of the RER stimulates output in Romania (a fraction of $y_{t}$ explained by changes in $q_{t}$ gradually declines from 25 to $12 \%$ ), with a weak contractionary effect in Poland and no effect in the Czech Republic and Hungary. In general, our results reflect the ambiguous policy implications of exchange rate depreciation in the IS-MP-IA model, and can be compared with quite heterogeneous findings in other studies (Clark \& Hsing 2005, pp. 297-311; Hsing 2004, pp. 339-45; Hsing 2005, pp. 44-50; Hsing \& Morgan 2017, pp. 24-30).

\section{Conclusions}

The IS-MP-IA model implies that the inflation target can be achieved with the response of the $\mathrm{CB}$ policy rate to the output gap and inflationary pressure. Our findings demonstrate that there is a strong response to the acceleration of inflation, though with a different time pattern. The reaction of the central bank appears to be almost immediate and short-lived in Poland and Hungary (to a lesser extent), with a downward correction in two years, while Romania and the Czech Republic are characterized by a more persistent but less significant response. On the other hand, there is no evidence of the central bank response to the output gap (except for Poland in the middle run and Romania in the long run). The reaction of inflation to an increase in the $\mathrm{CB}$ reference rate seems to be immediate and conventional in Poland, while the price puzzle is observed in all other countries. Real output increases over a year in the Czech Republic and Romania but then tends to fall below the trend in the long run (no output effects in Hungary and Poland). Except for Poland, an increase in the $\mathrm{CB}$ reference rate leads to a higher lending rate. Monetary tightening is associated with quite persistent RER undervaluation in Romania, while in the Czech Republic a short-term RER undervaluation is reversed in the middle-run. Among other results, it is worth mentioning that budget surplus has a strong anti-inflationary impact on all CEE countries but at the expense of a short-lived output slowdown (except for Hungary). As expected, an increase in the lending rate is followed by a short-lived fall in output, while there are no significant effects on inflation. Finally, RER undervaluation is likely to stimulate output (Romania) or depress it (Poland), with a neutral stance in the two other countries.

Our study implies that the response of the $\mathrm{CB}$ reference rate to the output gap should be much stronger. As suggested by the experience of Poland, the immediate response of the central bank to inflation could explain the lack 
of the price puzzle. An anti-inflationary monetary policy stance should be strengthened by fiscal tightening, while in a recession a higher budget deficit is likely to boost output and prevent a deflationary spiral. For future studies, it is of particular interest to identify possible changes in the monetary policy transmission mechanism in the present period of extremely low interest rates that potentially diminish the power of $\mathrm{CB}$ reference rate policy.

\section{Bibliography}

Apostolov, M. and Josevski, D. (2015) "Aggregate Demand-inflation Adjustment Model Applied to Southeast European Economies". Journal of Central Banking Theory and Practice 1: 131-57, https://doi.org/10.1515/jcbtp-2016-0007.

Arlt, G. and Mandel, M. (2014) "The Reaction Function of Three Central Banks of Visegrad Group”. Prague Economic Papers 23(3): 269-89, https://doi.org/10.18267/ j.pep.484.

Ball, L. (1999) "Policy Rules for Open Economies" in: J. B. Taylor (ed.) Monetary Policy Rules (127-56), University of Chicago Press.

Bofinger, P., Mayer, E. and Wollmershauser, T. (2006) "The BMW Model: A New Framework for Teaching Monetary Economics". Journal of Economic Education 37(1): 98-117, https://doi.org/10.3200/JECE.37.1.98-117.

Caporale, G. M., Helmi, M. H., Çatık, A. N., Ali, F. M. and Akdeniz, C. (2018) "Monetary Policy Rules in Emerging Countries: Is There an Augmented Nonlinear Taylor Rule?". Economic Modelling, 72(C): 306-19, https://doi.org/10.1016/j.econmod.2018.02.006.

Căpraru, B., Moise, N.I. and Rădulescu, A. (2015) "The Monetary Policy of the National Bank of Romania in the Inflation Targeting Era. A Taylor Rule Approach". Review of Economic \& Business Studies 8(2): 91-102.

Clark, D. P. and Hsing, Y. (2005) "Application of the IS-MP-IA Model and the Taylor Rule to Korea and Policy Implications". The Journal of the Korean Economy 6(2): 297-311.

Cochrane, J. (2016) "Do Higher Interest Rates Raise or Lower Inflation?”. Working Paper. Chicago: Chicago Booth School.

Crespo-Cuaresma, J., Eller, M. and Mehrotra, A. (2011) "The Economic Transmission of Fiscal Policy Shocks from Western to Eastern Europe”. BOFIT Discussion Papers 12. Helsinki: Bank of Finland.

Cúrdia, V., Ferrero, A., Ng, C. C. and Tambalotti, A. (2015) "Has U.S. Monetary Policy Tracked the Efficient Interest Rate?". Journal of Monetary Economics 70(1): 72-83, https://doi.org/ 10.1016/j.jmoneco.2014.09.004.

Darvas, Z. (2006) "Monetary Transmission in the New EU Member States: Evidence from Time-varying Coefficient Vector Autoregression”. Focus on European Economic Integration Q1/06: 140-55.

Dąbrowski, M., Papież, M. and Śmiech, S. (2018) "Uncovering the Link between a Flexible Exchange Rate and Fundamentals: The Case of Central and Eastern European Economies". Applied Economics 50(20): 2273-96, https://doi.org/10.1080/ 00036846.2017.1394974. 
Feldkircher, M., Huber, F. and Moder, I. (2016) "Modeling the Evolution of Monetary Policy Rules in CESEE". Focus on European Economic Integration Q1/16: 8-27.

Frömmel, M., Garabedian, G. and Schobert, F. (2011) "Monetary Policy Rules in Central and Eastern European Countries: Does the Exchange Rate Matter?". Journal of Macroeconomics 33(4): 807-18, https://doi.org/10.1016/j.jmacro.2011.05.003.

Giordani, P. (2004) "An Alternative Explanation of the Price Puzzle". Journal of Monetary Economics 51(6): 1271-96, https://doi.org/10.1016/j.jmoneco.2003.09.006.

Hanson, M. (2004) “The 'Price Puzzle' Reconsidered”. Journal of Monetary Economics 51(7): 1385-413, https://doi.org/10.1016/j.jmoneco.2003.12.006.

Haug, A., Jędrzejowicz, T. and Sznajderska, A. (2019) "Monetary and Fiscal Policy Transmission in Poland". Economic Modelling 79(1): 15-27, https://doi.org/10.1016/j. econmod.2018.09.031.

Heipertz, J., Mihov, I. and Santacreu, A. M. (2017) “The Exchange Rate as an Instrument of Monetary Policy”. FRB of St. Louis Working Papers 28. St. Louis: Federal Reserve Bank of St. Louis.

Hsing, Y. (2004) "Impacts of Macroeconomic Policies on Output in the Czech Republic: An Application of Romer's IS-MP-IA Model”. Prague Economic Papers 2004(4): 339-45, https://doi.org/10.18267/j.pep.246.

Hsing, Y. (2005) "Short-term Output Fluctuations in Poland: An Application of the IS-MP-AS Model". The American Economist 49(2): 44-50.

Hsing, Y. and Morgan, Y.C. (2017) "Is Real Depreciation and Expansionary Fiscal Policy Effective? The Case of Serbia". Economics, Management and Sustainability 2(2): 24-30, https://doi.org/10.14254/ jems.2017.2-2.3.

Josheski, D. and Eftimoski, D. (2016) "Application of IS-MP-IA Model and Taylor Rule to CESEE Economies". Economics and Culture 13(1): 5-13, https://doi.org/10.1515/ jec-2016-0001.

Klose, J. (2019) "Are Eastern European Taylor Reaction Functions Asymmetric in Inflation or Output: Empirical Evidence for Four Countries". Eastern European Economics 57(1): 31-49, https://doi.org/10.1080/00128775.2018.1517600.

Lee, K. S. and Werner, R. (2018) "Reconsidering Monetary Policy: An Empirical Examination of the Relationship Between Interest Rates and Nominal GDP Growth in the U.S., U.K., Germany and Japan”. Ecological Economics 146(1): 26-34, https:// doi.org/10.1016/j.ecolecon.2017.08.013.

Leitemo, K. and Söderström, U. (2005) "Simple Monetary Policy Rules and Exchange Rate Uncertainty”. Journal of International Money and Finance 24(3): 481-507, https://doi.org/ 10.1016/j.jimonfin.2005.01.001.

Mackiewicz-Łyziak, J. (2016) "Active and Passive Monetary Policy in CEE Countries with Inflation Targeting: The Case of the Czech Republic, Hungary, and Poland". Eastern European Economics 54(2): 133-52, https://doi.org/10.1080/00128775.2015.1126789.

Nojković, A. and Petrović, P. (2015) "Monetary Policy Rule in Inflation Targeting Emerging European Countries: A Discrete Choice Approach". Journal of Policy Modeling 37(4): 577-95, https://doi.org/10.1016/j.jpolmod.2015.03.016.

Orlowski, L. (2010) "Monetary Policy Rules for Convergence to the Euro". Economic Systems 34(2): 148-59, https://doi.org/10.1016/j.ecosys.2009.09.005.

Paez-Farrell, J. (2007) "Understanding Monetary Policy in Central European Countries Using Taylor-type Rules: The Case of the Visegrad Four". Economics Bulletin 5(3): $1-11$. 
Popescu, I. V. (2014) "Analysis of the Behavior of Central Banks in Setting Interest Rates. The Case of Central and Eastern European Countries". Procedia Economics and Finance 15: 1113-21, https://doi.org/10.1016/s2212-5671(14)00565-6.

Pourroy, M. (2013) "Inflation-targeting and Foreign Exchange Interventions in Emerging Economies". Documents de travail du Centre d'Economie de la Sorbonne 74.

Romer, D. (2000) "Keynesian Macroeconomics without the LM Curve". Journal of Economic Perspectives 14(2): 149-69, https://doi.org/10.1257/jep.14.2.149.

Ryczkowski, M. (2016) "Poland as an Inflation Nutter: The Story of Successful Output Stabilization". Zbornik radova Ekonomskog fakulteta u Rijeci 34(2): 363-92, https:// doi.org/ 10.18045/zbefri.2016.2.363.

Shieh, Y. N. (2006) "IS-MP-AS Approach to Currency Devaluation". International Journal of Applied Economics 3(1): 65-70.

Taylor, J. (2000) "Reassessing Discretionary Fiscal Policy". Journal of Economic Perspectives 14(3): 21-36, https://doi.org/10.1257/jep.14.3.21.

Vašiček, B. (2012) "Is Monetary Policy in the New EU Member States Asymmetric?", Economic Systems 46(2): 235-63, https://doi.org/10.1016/j.ecosys.2011.07.003.

Wang, Y., Jiang, C., Chang, H. L. and Su, C. W. (2015) "Are Taylor Rules Valid in Central Eastern European Countries?”. Ekonomický časopis 63(7): 665-85. 